\title{
Demographic Study of Female Victims of Sexual Violence Referred to Forensic Medicine in Fars Province
}

\author{
${ }^{1}$ Vaziri F, ${ }^{2}$ Ghodrati F, ${ }^{3}$ Saadatmand N, ${ }^{4}$ Zarenezhad M, ${ }^{1}$ Foruhari S, ${ }^{5}$ Akbarzadeh M \\ ${ }^{1}$ Community Based Psychiatric Care Research Center, Department of Midwifery, School of Nursing and \\ Midwifery, Shiraz University of Medical Sciences, Shiraz, Iran. \\ ${ }^{2}$ Department of Theology, Faculty of Humanities Science College, ${ }^{3}$ Department of midwifery, Gachsaran \\ Branch, Islamic Azad University, Gachsaran, Iran. \\ ${ }^{4}$ Legal Medicine Research Center, Legal Medicine Organization, Tehran, Iran. \\ ${ }^{5}$ Maternal -fetal Medicine Research Center, Department of Midwifery, School of Nursing and Midwifery, \\ Shiraz University of Medical Sciences, Shiraz, Iran.
}

Received: 30 November 2018; Accepted: 12 December 2018

DOI: $10.3126 /$ njog.v13i3.23428

ABSTRACT

Aims: To determine the clients' profile of referred in female victims of sexual violence.

Methods: In a period of 7 years (2006-2012), 2113 cases of plaintiffs complaining about women sexual violence were investigated by a questionnaire after receiving permission from Shiraz University of Medical Sciences and Forensic Medicine Organization. Data were analyzed after entering SPSS software, version 16, using descriptive statistics and chi-square

Results: The prevalence of rape has decreased in different ages. In 1668 cases, the plaintiffs were female (78.93 \%) and most of the victims $(36.5 \%)$ aged between 16 and 25 years old. According to Fisher test, there was a significant relationship between the age of the victims and different years of examination $(\mathrm{p} \leq 0.001)$. The highest frequency of $30 \%$ is reported at elementary education level. The highest frequency of sexual violence against women (18.3\%) was reported in 2006 followed by $18.2 \%$ in 2011 . In terms of occupation, the highest frequency of victims was related to students estimated as $40.52 \%$.

Conclusions: Because of the unpleasant nature of sexual violence, there is a serious need for urgent and necessary consideration of its harmful effects and root out this social dilemma by policy makers. Sexual abuse must be prevented especially using religious achievements or by developing effective control strategies detected and by experience female health care users treated.

Key words: female, forensic medicine, sexual violence, victims

\section{INTRODUCTION}

Undoubtedly, sexual violence and harassment, as one of a variety of social deviations, is considered among the most important disorder factors which disrupts the cultural and social affairs as well as order and discipline of the communities. Meanwhile, the Islamic legal system and the resulting criminal policy strongly react to sexual deviations generally and violence and harassment, in particular. ${ }^{1,2}$ Because there is a reasonable relationship between the family and community health and safety and security for

\section{CORRESPONDENCE}

Marzieh Akbarzadeh

Maternal -fetal Medicine Research Center, Department of Midwifery, School of Nursing and Midwifery, Shiraz University of Medical Sciences, Shiraz, Iran.

Email: akbarzadm@sums.ac.ir individuals, especially women, is based on the foundation of the family, and on the other hand, it adds to the ability of the community and prevents harm to the vast and influential sectors of society, then violence must be discussed as a major social problem. In this way, it helps to ensure the health, safety and stability of the family and, consequently, the health and safety of the community. ${ }^{3,4}$ Annually, millions of women and children around the world are victims of attacks, rape and sexual abuse. In recent years, official statistics in all countries have confirmed a significant increase in this category of crimes. ${ }^{5}$ Sexual violence 
refers to any form of violent sexual behavior of one person to another despite her /his opposition. This violent sexual behavior can be motivated by threats, abuse, injury and sexual harm. ${ }^{1,6}$ A WHO study on women health and violence against women, its data gathered from a study of more than 24 thousand women in 15 regions from 10 countries, indicated that the frequency of physical or sexual violence, or both of them, by sexual partner was $15-71 \%$ during the lifetime and $29-62 \%$ in most areas. ${ }^{7}$ It is estimated that out of every five women one person faces a form of violence in their lifetime. In some cases, it can lead to serious injury or death. Today, most governments paid attention to violence against women in general and violence by a husband or other sexual partner in relative terms as a social problem of society. ${ }^{8}$

Violence against women is a major threat to economic and social development. General Assembly of United Nations presented some plans to confront all forms of violence against women and to implement the Convention on the Elimination of All Forms of Discrimination against Women. ${ }^{9}$ According to the WHO report, in the first international study on types of violence, 150 million girls and 73 million boys under the age of 18 were sexually abused in the world just in $2002 .{ }^{10}$ Study conducted in Iran (2010) showed that $22.8 \%$ of the $(1,495$ high school students) reporting violence between their parents. ${ }^{11}$ Based on the conducted studies, other research refers to a variety of domestic violence and less violence and sexual abuse have been reported in Iran. ${ }^{12-14}$

In a study in Iran, for screening and determining the extent of intimate partner violence, the prevalence of physical, psychological and sexual abuse against women was $43.7 \%, 82.6 \%$ and $30.9 \%$ respectively. ${ }^{15}$ It was indicated that sexual violence was $28.6 \%$ and the most common type of sexual violence, sexual relationship by force, in this study was $13.1 \%{ }^{16}$ The aim of this study was to investigate the demographic characteristics of female victims of sexual violence (rape) who referred to Fars Forensic Medicine between $2006-2012$.

\section{METHODS}

This retrospective study was conducted to investigate plaintiffs in cases of women sexual violence over a period of 7 years (2006-2012(.Out of 3240 cases 2113 had required information. In this study, the demographic data of female plaintiffs of sexual violence were studied. The data were analyzed after entering the SPSS software, version 16. Descriptive statistics (frequency and percentage) were used for data analysis. Approval was taken from Shiraz University of Medical Sciences and Forensic Medicine Organization.

\section{RESULTS}

A total of 2113 victims of were reported at the Fars Forensic Medicine Centre over a seven-year period (2006-2012); there were 1668 female plaintiffs $(78.93 \%)$. Of these, it was reported that most of the victims $(609 ; 36.5 \%)$ aged $16-25$ years old followed by those who aged 6-15 years old (32\%). The lowest incidence of violence was over the age of 35 (6.7\%). According to Fisher test, significant correlation was found between the age of the victims and different years of examination $(p \leq 0.001)$ [Table-1].

Table-1: The relationship between age and sexual violence victims in different years

\begin{tabular}{|c|c|c|c|c|c|c|c|}
\hline \multicolumn{2}{|c|}{ Year } & $<5$ & $6-15$ & $16-25$ & $26-35$ & $35>$ & Total \\
\hline \multirow[t]{2}{*}{2006} & $\mathrm{~N}$ & 38 & 114 & 98 & 35 & 21 & 306 \\
\hline & $\%$ & $12.4 \%$ & $37.3 \%$ & $32.0 \%$ & $11.4 \%$ & $6.9 \%$ & $100.0 \%$ \\
\hline \multirow[t]{2}{*}{2007} & $\mathrm{~N}$ & 14 & 64 & 86 & 40 & 6 & 210 \\
\hline & $\%$ & $6.7 \%$ & $30.5 \%$ & $41.0 \%$ & $19.0 \%$ & $2.9 \%$ & $100.0 \%$ \\
\hline \multirow[t]{2}{*}{2008} & $\mathrm{~N}$ & 23 & 71 & 96 & 38 & 20 & 248 \\
\hline & $\%$ & $9.3 \%$ & $28.6 \%$ & $38.7 \%$ & $15.3 \%$ & $8.1 \%$ & $100.0 \%$ \\
\hline \multirow[t]{2}{*}{2009} & $\mathrm{~N}$ & 21 & 56 & 62 & 37 & 14 & 190 \\
\hline & $\%$ & $11.1 \%$ & $29.5 \%$ & $32.6 \%$ & $19.5 \%$ & $7.4 \%$ & $100.0 \%$ \\
\hline \multirow[t]{2}{*}{2010} & $\mathrm{~N}$ & 14 & 61 & 69 & 32 & 10 & 186 \\
\hline & $\%$ & $7.5 \%$ & $32.8 \%$ & $37.1 \%$ & $17.2 \%$ & $5.4 \%$ & $100.0 \%$ \\
\hline \multirow[t]{2}{*}{2011} & $\mathrm{~N}$ & 35 & 96 & 115 & 36 & 22 & 304 \\
\hline & $\%$ & $11.5 \%$ & $31.6 \%$ & $37.8 \%$ & $11.8 \%$ & $7.2 \%$ & $100.0 \%$ \\
\hline \multirow[t]{2}{*}{2012} & $\mathrm{~N}$ & 20 & 72 & 83 & 31 & 18 & 224 \\
\hline & $\%$ & $8.9 \%$ & $32.1 \%$ & $37.1 \%$ & $13.8 \%$ & $8.0 \%$ & $100.0 \%$ \\
\hline \multirow[t]{2}{*}{ total } & $\mathrm{N}$ & 165 & 534 & 609 & 249 & 111 & 1668 \\
\hline & $\%$ & $9.9 \%$ & $32.0 \%$ & $36.5 \%$ & $14.9 \%$ & $6.7 \%$ & $100.0 \%$ \\
\hline
\end{tabular}

* Fisher's Exact Test

; PV: $\leq 0.001$ 
The average rate of rape among 16-25 women was 0.46/10,000 adult women in 2006. It was a decreased from $0.46 / 10,000$ to $0.30 / 10,000$ in 2010 . The average rate of rape among over 35 years women was $0.098 / 10,000$ adult women in 2006 that decreased to $0.044 / 10,000$ women in 2010 [Table-2].

Table-2: The Ratio violence victims in 10,000 women of different ages in 2006 and 2010

\begin{tabular}{|l|l|l|l|l|l|l|l|}
\hline \multicolumn{2}{|l|}{ Year } & $<5$ & $6-15$ & $16-25$ & $26-35$ & $35>$ & Total \\
\hline \multirow{2}{*}{2006} & $\mathrm{~N}$ & 38 & 114 & 98 & 35 & 21 & 306 \\
\cline { 2 - 8 } & The ratio of 10,000 women* & 0.178 & 0.53 & 0.46 & 0.16 & 0.098 & 1.44 \\
\hline \multirow{2}{*}{2011} & $\mathrm{~N}$ & 35 & 96 & 115 & 36 & 22 & 304 \\
\cline { 2 - 8 } & The ratio of 10,000 women** & 0.06 & 0.26 & 0.30 & 0.14 & 0.044 & 0.82 \\
\hline
\end{tabular}

The highest frequency of sexual abuse by victims' educational level was of same proportion of around 30\% each year [Table-3].

Table-3: The relationship between educations and sexual violence victims in different years

\begin{tabular}{|c|c|c|c|c|c|c|c|c|c|}
\hline & undermined & $\begin{array}{l}\text { Under the age } \\
\text { of literacy }\end{array}$ & illiterate & $\begin{array}{l}\text { Primary } \\
\text { school }\end{array}$ & $\begin{array}{l}\text { Secondary } \\
\text { school }\end{array}$ & $\begin{array}{l}\text { Associate } \\
\text { Degree }\end{array}$ & BSC & total & \\
\hline \multirow[t]{2}{*}{2006} & $\mathrm{~N}$ & 9 & 38 & 40 & 112 & 82 & 16 & 9 & 306 \\
\hline & $\%$ & $2.9 \%$ & $12.4 \%$ & $13.1 \%$ & $36.6 \%$ & $26.8 \%$ & $5.2 \%$ & $2.9 \%$ & $100 \%$ \\
\hline \multirow[t]{2}{*}{2007} & $\mathrm{~N}$ & 7 & 14 & 27 & 53 & 74 & 25 & 10 & 210 \\
\hline & $\%$ & $3.3 \%$ & $6.7 \%$ & $12.9 \%$ & $25.2 \%$ & $35.2 \%$ & $11.9 \%$ & $4.8 \%$ & $100.0 \%$ \\
\hline \multirow[t]{2}{*}{2008} & $\mathrm{~N}$ & 5 & 23 & 41 & 68 & 78 & 26 & 7 & 248 \\
\hline & $\%$ & $2.0 \%$ & $9.3 \%$ & $16.5 \%$ & $27.4 \%$ & $31.5 \%$ & $10.5 \%$ & $2.8 \%$ & $100.0 \%$ \\
\hline \multirow[t]{2}{*}{2009} & $\mathrm{~N}$ & 4 & 21 & 29 & 53 & 49 & 30 & 4 & 190 \\
\hline & $\%$ & $2.1 \%$ & $11.1 \%$ & $15.3 \%$ & $27.9 \%$ & $25.8 \%$ & $15.8 \%$ & $2.1 \%$ & $100.0 \%$ \\
\hline \multirow[t]{2}{*}{2010} & $\mathrm{~N}$ & 2 & 14 & 33 & 56 & 52 & 26 & 3 & 186 \\
\hline & $\%$ & $1.1 \%$ & $7.5 \%$ & $17.7 \%$ & $30.1 \%$ & $28.0 \%$ & $14.0 \%$ & $1.6 \%$ & $100.0 \%$ \\
\hline \multirow[t]{2}{*}{2011} & $\mathrm{~N}$ & 6 & 35 & 55 & 84 & 94 & 28 & 2 & 304 \\
\hline & $\%$ & $2.0 \%$ & $11.5 \%$ & $18.1 \%$ & $27.6 \%$ & $30.9 \%$ & $9.2 \%$ & $0.7 \%$ & $100.0 \%$ \\
\hline \multirow[t]{2}{*}{2012} & $\mathrm{~N}$ & 8 & 20 & 37 & 74 & 63 & 21 & 1 & 224 \\
\hline & $\%$ & $3.6 \%$ & $8.9 \%$ & $16.5 \%$ & $33.0 \%$ & $28.1 \%$ & $9.4 \%$ & $0.4 \%$ & $100.0 \%$ \\
\hline \multirow[t]{2}{*}{ total } & $\mathrm{N}$ & 41 & 165 & 262 & 500 & 492 & 172 & 36 & 1668 \\
\hline & $\%$ & $2.5 \%$ & $9.9 \%$ & $15.7 \%$ & $30.0 \%$ & $29.5 \%$ & $10.3 \%$ & $2.2 \%$ & $100.0 \%$ \\
\hline
\end{tabular}

Pearson Chi-Square; value: 59.040 , df:36, pv:0.009

The highest number of sexual violence against women (over 300) was reported in 2006 and 2011 [Table-4].

Table-4: Frequency of victims of sexual violence in different years

\begin{tabular}{|c|c|c|}
\hline \multicolumn{2}{|l|}{ Year } & Frequency \\
\hline \multirow[t]{2}{*}{2006} & $\mathrm{~N}$ & 306 \\
\hline & $\%$ & $18.3 \%$ \\
\hline \multirow[t]{2}{*}{2007} & $\mathrm{~N}$ & 210 \\
\hline & $\%$ & $12.6 \%$ \\
\hline \multirow[t]{2}{*}{2008} & $\mathrm{~N}$ & 248 \\
\hline & $\%$ & $14.9 \%$ \\
\hline \multirow[t]{2}{*}{2009} & $\mathrm{~N}$ & 190 \\
\hline & $\%$ & $11.4 \%$ \\
\hline \multirow[t]{2}{*}{2010} & $\mathrm{~N}$ & 186 \\
\hline & $\%$ & $11.2 \%$ \\
\hline \multirow[t]{2}{*}{2011} & $\mathrm{~N}$ & 304 \\
\hline & $\%$ & $18.2 \%$ \\
\hline \multirow[t]{2}{*}{2012} & $\mathrm{~N}$ & 224 \\
\hline & $\%$ & $13.4 \%$ \\
\hline \multirow[t]{2}{*}{ total } & $\mathrm{N}$ & 1668 \\
\hline & $\%$ & $100.0 \%$ \\
\hline
\end{tabular}


In terms of occupation, the highest frequency of victims were students $(40.52 \%)$ followed by unemployed people. The lowest frequency was in below working age and workers reported as $2.15 \%$ and $3.65 \%$ respectively [Table-5].

Table-5: The relationship between distribution of jobs and sexual violence victims in different years

\begin{tabular}{|c|c|c|c|c|c|c|c|c|c|}
\hline \multicolumn{2}{|c|}{ Variable } & \multirow{2}{*}{\begin{tabular}{|l|}
$\begin{array}{l}\text { Under } \\
\text { the age }\end{array}$ \\
Job
\end{tabular}} & \multirow[t]{2}{*}{ housewife } & \multirow{2}{*}{$\begin{array}{l}\text { Non- } \\
\text { Governmental }\end{array}$} & \multirow[t]{2}{*}{ Governmental } & \multirow[t]{2}{*}{ Unemployed } & \multirow[t]{2}{*}{ students } & \multirow[t]{2}{*}{ undetermined } & \multirow[t]{2}{*}{ total } \\
\hline \multicolumn{2}{|l|}{ Year } & & & & & & & & \\
\hline \multirow[t]{2}{*}{2006} & $\mathrm{~N}$ & 20 & 38 & 26 & 10 & 32 & 180 & 0 & 306 \\
\hline & $\%$ & $32.8 \%$ & $15.4 \%$ & $17.3 \%$ & $9.9 \%$ & $14.3 \%$ & $26.6 \%$ & $0.0 \%$ & $18.3 \%$ \\
\hline \multirow[t]{2}{*}{2007} & $\mathrm{~N}$ & 11 & 28 & 18 & 5 & 24 & 121 & 3 & 210 \\
\hline & $\%$ & $18.0 \%$ & $11.4 \%$ & $12.0 \%$ & $5.0 \%$ & $10.8 \%$ & $17.9 \%$ & $1.4 \%$ & $12.6 \%$ \\
\hline \multirow[t]{2}{*}{2008} & $\mathrm{~N}$ & 13 & 31 & 29 & 23 & 26 & 124 & 2 & 248 \\
\hline & $\%$ & $21.3 \%$ & $12.6 \%$ & $19.3 \%$ & $22.8 \%$ & $11.7 \%$ & $18.3 \%$ & $0.9 \%$ & $14.9 \%$ \\
\hline \multirow[t]{2}{*}{2009} & $\mathrm{~N}$ & 10 & 40 & 20 & 18 & 32 & 65 & 5 & 190 \\
\hline & $\%$ & $16.4 \%$ & $16.3 \%$ & $13.3 \%$ & $17.8 \%$ & $14.3 \%$ & $9.6 \%$ & $2.4 \%$ & $11.4 \%$ \\
\hline \multirow[t]{2}{*}{2010} & $\mathrm{~N}$ & 0 & 0 & 0 & 0 & 0 & 0 & 186 & 186 \\
\hline & $\%$ & $0.0 \%$ & $0.0 \%$ & $0.0 \%$ & $0.0 \%$ & $0.0 \%$ & $0.0 \%$ & $88.2 \%$ & $11.2 \%$ \\
\hline \multirow[t]{2}{*}{2011} & $\mathrm{~N}$ & 4 & 69 & 36 & 27 & 73 & 88 & 7 & 304 \\
\hline & $\%$ & $6.6 \%$ & $28.0 \%$ & $24.0 \%$ & $26.7 \%$ & $32.7 \%$ & $13.0 \%$ & $3.3 \%$ & $18.2 \%$ \\
\hline \multirow[t]{2}{*}{2012} & $\mathrm{~N}$ & 3 & 40 & 21 & 18 & 36 & 98 & 8 & 224 \\
\hline & $\%$ & $4.9 \%$ & $16.3 \%$ & $14.0 \%$ & $17.8 \%$ & $16.1 \%$ & $14.5 \%$ & $3.8 \%$ & $13.4 \%$ \\
\hline \multirow[t]{2}{*}{ total } & $\mathrm{N}$ & 61 & 246 & 150 & 101 & 223 & 676 & 211 & 1668 \\
\hline & $\%$ & $100.0 \%$ & $100.0 \%$ & $100.0 \%$ & $100.0 \%$ & $100.0 \%$ & $100.0 \%$ & $100.0 \%$ & $100.0 \%$ \\
\hline
\end{tabular}

Pearson Chi-Square; value: 1586.591, df: $36, \quad$ PV: $\leq 0.001$

From 2006 to 2009, it was reported that most victims of sexual violence were housewives and schoolchildren while the lowest incidence of violence was in women below working age and self- employed workers. In 2010 and 2011, most women were studying and the lowest number of women was workers. In 2012, only $47 \%$ were below working age [Table-6].

Table-6: Frequency of family characteristic of victim in female sexual violence victims

\begin{tabular}{|l|l|l|l|}
\hline variables & N (\%) & variables & N (\%) \\
\hline Number of child & $\begin{array}{l}\text { Relationship between the } \\
\text { offender and the victim }\end{array}$ & \\
\hline$<4$ & $293(17.75)$ & friend & $398(23.86)$ \\
\hline $5-10$ & $957(57.37)$ & The house & $7(0.41)$ \\
\hline $11>$ & $154(9.23)$ & families & $251(15.04)$ \\
\hline undetermined & $264(15.82)$ & Non-familiars & $825(49.46)$ \\
\hline Rank child & & classmate & $22(1.31)$ \\
\hline$<3$ & $213(12.76)$ & neighbor & $133(7.97)$ \\
\hline $4-6$ & $856(51.31)$ & Teacher & $19(1.13)$ \\
\hline $7-9$ & $336(20.14)$ & fellow & $13(0.77)$ \\
\hline Unknown & $263(15.76)$ & Having parents & \\
\hline Time of the crime & & yes & $1087(65.16)$ \\
\hline Morning & $137(8.21)$ & No & $302(18.10$ \\
\hline Noon & $439(26.31)$ & undetermined & $279(16.72)$ \\
\hline Evening & $87(5.21)$ & & \\
\hline night & $828(49.64)$ & & \\
\hline undetermined & $177(10.61)$ & & \\
\hline
\end{tabular}




\section{DISCUSSION}

Sexual violence occurs all over the world, though in many countries there is little research conducted on this issue. Because of the private nature of sexual violence, it is difficult to estimate the extent of this problem. ${ }^{6}$ In our study, $78.93 \%$ of sexual violence plaintiffs were female where as the proportion varies from one study to another like $93.9 \%$ (Ezechi OC et al17) and $40 \%$ (United States ${ }^{18}$ ).

In our study, the highest frequency of sexual assault belonged to female victims aged 16-25 and the lowest frequency was reported for women over 35 year old. This amount of frequency increased somewhat from 2006 to 2011. Results of a retrospective study of French Forensic reports during a seven-year period indicated that among a total of 756 cases during the study period, the mean age of the subjects was 16.5 years old and in $31.7 \%$ of cases, the victims were aged 15 years old or more. In official criminal charges, $46.2 \%$ of cases had no sufficient evidence and in $36.3 \%$ of cases the sex offenders were convicted. ${ }^{19}$

Ezechi et a ${ }^{12}$ reported sexual assault as higher in single girls and women over the age of 20 and Isfahan 20 also showed a significant relationship between marital status and sexual abuse.

A review by Mirzaee et $\mathrm{al}^{21}$ indicated $12-35 \%$ of women having sexual abuse before the age of 18 . Another study ${ }^{22}$ in Tehran reported it between 20 and 30 . The above studies are consistent with the results of our studies. Studies show that women are eight times more prone to violence. ${ }^{6}$ Adolescents victims aged 16-24 years are more exposed to rape than the other age groups. ${ }^{23-25}$

Young age, lack of social protection and being alone were the risk factors for women to be exposed to violence and rape. ${ }^{26}$ In our study, in terms of education, the highest frequency of sexual abuse victims was among low educated people (elementary) while in terms of occupation was among students and unemployed people with a higher frequency reported in 2011 and 2012.

In one study, 7603 students were investigated for sexual assault among which nearly 20 percent of the samples reported a widespread experience of SA. The prevalence of sexual assault was significantly higher in women compared to men. Victims were at greater risk before coming to college (at school time). ${ }^{27}$ The findings from the first large study of Canadian women since the 1990s shows that a large proportion of women at university experienced a history of sexual assault in the pre-university period. ${ }^{28}$ Mostly unemployed 22 and pre-University disable students $(18 \%)$ had sexual assault with rape in $15 \% .^{29}$

Adolescents are more likely to experience disastrous situations of psychological stress and general health problems than others. ${ }^{30}$ There was no significant relationship between work place (public and private) and sexual harassment. ${ }^{20}$ About $80 \%$ of sexual assaults is not reported for various reasons..$^{21,31}$

\section{CONCLUSIONS}

The prevalence of rape has decreased in different ages and the most female victims were aged between 16 and 25 , had primary education and were students. A high rate of rape frequency observed in the years of 2006 and 2011.

Acknowledgements: The authors would like to thank Shiraz University of Medical Sciences, Shiraz, Iran and also Center for Development of Clinical Research of Nemazee Hospital for data analysis; and Dr Raeisi Shahraki and Dr. Nasrin Shokrpour for editorial assistance.

\section{REFERENCES}

1. Eshaghi M. Sexual harassment of women and their types Strategic Studies Women. 2003;5(20):173-202. http://www magiran.com/magtoc .asp ?mgID $=1071 \&$ Number $=20 \&$ Appen $\operatorname{dix}=0$

2. Zhang D, Zhou C, Yang L, Sun T, Hao T. A cross-sectional study on the prevalence and associated risk factors for workplace violence against Chinese nurses. BMJ Open 2017;7(6):e013105. DOI:: 10.1136/bmjopen-2016-013105.

3. Hezavehyee M. Violence semantics. Strategic Studies Women. 2003;6(23):14-40. http://www.magiran.com/magtoc asp? $\mathrm{mgID}=1071 \&$ Number $=23$
4. Oram S, Khalifeh H, Howard LM. Violence against women and mental health. Lancet Psychiatry. 2017;4(2):159-70. DOI:: 10.1016/S2215-0366(16)30261-9.

5. Mathews B, Bromfield L, Walsh K, Cheng Q, Norman RE Reports of child sexual abuse of boys and girls: Longitudinal trends over a 20-year period in Victoria, Australia. Child Abuse Negl. 2017;66:9-22. DOI:: .1016/j.chiabu.2017.01.025

6. Hemmati R. Factors Influencing Women Harassment: The Case Study of Tehran Family . Social Welfare. 2004;3(12):22756. URL: http://refahj.uswr.ac.ir/article-1-1884-fa.html

7. World Health Organization. Addressing violence against 
women and achieving the Millennium Development Goals, Department of Gender, Women and Health Family and Community Health. 2005

8. Grown C, Gupta GR, A Kes. Taking Action: achieving gender equality and empowering women. UN Millennium Project, Task Force on Education and Gender Equality, London, Earth scan, 2005

9. Resolution $\mathrm{A} / \mathrm{RES} / 55 / 2$. The United Nations Millennium Declaration, New York, United Nations, 8 September 2000 (http://www.un.org/millennium/declaration/ares552e.htm)

10. WHO. Global Estimates of Health Consequences Due to Violence against Children. Background Paper to the UN Secretary General Study on Violence against Children. Geneva: World Health Organization, 2006

11. Vameghi M, Feizzadeh A, Mirabzadeh A, Feizzadeh G Exposure to domestic violence between parents: a perspective from Tehran, Iran. Journal of Interpersonal Violence. 2010;25(6):1006-21

12. Ghahhari S, Mazdarani S, Khalilian A, Zarghami M. Spouse abuse in Sari-Iran. Iranian Journal of Psychiatry and Behavioral Sciences. 2008;2(1):31-5

13. Sheikhattari P, Stephenson R, Assasi N, Eftekhar H, Zamani Q, Maleki B, et al. Child Maltreatment among School Children in Kurdistan Province, Iran. Child Abuse and Neglect. 2006;30:231-45

14. Fadardi JS, Ziaee SS. A comparative study of anxiety, stress, and depression in physically abused and non-abused Iranian wives. Iranian Journal of Psychiatry and Behavioral Sciences. 2009;3(2):15-24.

15. Vakili $M$, Nadrian $H$, Fathipoor $M$, Boniadi $F$, Morowatisharifabad MA. Prevalence and determinants of intimate partner violence against women in Kazeroon, Islamic Republic of Iran. Violence Vict. 2010;25(1):116-27

16. Meybodi B, Hussaini M. Prevalence of Violence Against Women by their Partners in Kerman. IJPCP. 2009;15(3):3007. URL: http://ijpcp.iums.ac.ir/article-1-829-en.html

17. Ezechi OC, Adesolamusa Z, David AN, Wapmuk AE, Gbajabiamila TA, Eugeniaidigbe I, et al. Trends and patterns of sexual assaults in Lagos south-western Nigeria. Pan Afr Med J. 2016;24:261. eCollection 2016.

18. Amin P, Buranosky R, Chang JC. Physicians' Perceived Roles, as Well as Barriers, Toward Caring for Women Sex Assault Survivors. Womens Health Issues. 2017;27(1):43-9. DOI:: 10.1016/j.whi.2016.10.002. 2016 Nov 15

19. Saint-Martin P, Bouyssy M, O'Byrne P. Analysis of 756 cases of sexual assault in Tours (France): medico-legal findings and judicial outcomes. Medicine, Science and the Law. 2007;47(4):24-315.

20. Fatemi A, Investigating the Effect of Attitudes toward Hijab Coverage on Sexual Abuse in the streets and vehicles. (Case study: Women aged 18 to 29 years old in Isfahan). Available at http://www.migna.ir/vdceov8z.jh8f7i9bbj.html] in 2017

21. Mirzayee J, Khodayee M, Mohamadkhani P. The effects of sexual violence on prevalence of PTSD. Journal of Rehabilitation. 2004;7(4):65-72. Available at URL: http:// fa.journals.sid.ir/ViewPaper.aspx?ID=58864

22. Vasegh Rahimparvar S F, Mottaghi B, Daneshparvar H, Jafari A. The Study of Post-Traumatic Stress Disorder in Women Complaining of Rape Referred to Legal Medicine Center in Tehran in 2013. IJFM. 2015;21(1):47-52. URL: http://sjfm.ir/ article-1-663-en.html

23. Linz DG, Donnerstein E, Penrod S. Effects of long-term exposure to violent and sexually degrading depictions of women. Pers Soc Psychol. 1988;55(5):758-68.

24. Rosellini AJ, Street AE, Ursano RJ, Chiu WT, Heeringa SG, Monahan J, et al. Sexual Assault Victimization and Mental Health Treatment, Suicide Attempts, and Career Outcomes Among Women in the US Army. Am J Public Health 2017;107(5):732-9. DOI:: 10.2105/AJPH.2017.303693. Epub 2017 Mar 21.

25. Rennison CM, 1993-99. Intimate partner violence and age of victim. U.S. Department of Justice, Office of Justice Programs, Bureau of Justice Statistics, 2001. URL: http://bjs.ojp.usdoj. gov/content/pub/pdf/ipva99.pdf (Accessed on April 27, 2011).

26. Lövestad S, Krantz. G. Men's and women's exposure and perpetration of partner violence: an epidemiological study from Sweden. BMC Public Health. 2012;12:945. DOI: 10.1186/1471-2458-12-945.

27. Conley AH, Overstreet CM, Hawn SE, Kendler KS, Dick DM, Amstadter AB. Prevalence and predictors of sexual assault among a college sample. J Am Coll Health. 2017;65(1):41-9. DOI:: 10.1080/07448481.2016.1235578. Epub 2016 Sep 14

28. Senn CY, Eliasziw M, Barata PC, Thurston WE, NewbyClark IR, Radtke HL, Hobden KL; SARE Study Team. Sexual violence in the lives of first-year university women in Canada: no improvements in the 21 st century. BMC Womens Health. 2014; 14:135. DOI:: 10.1186/s12905-014-0135-4

29. Carey KB1, Durney SE2, Shepardson RL3, Carey MP4. Incapacitated and forcible rape of college women: prevalence across the first year. J Adolesc Health. 2015;56(6):678-80. DOI:: 10.1016/j.jadohealth.2015.02.018.

30. Smith PN, Gamble SA, Cort NA, Ward EA, Conwell Y, Talbot NL. The relationships of attachment style and social maladjustment to death ideation in depressed women with a history of childhood sexual abuse. Journal of Clinical Psychology. 2012:68:78-87.

31. Grubb A, Turner E. Attribution of blame in rape cases: A review of the impact of rape myth acceptance,gender role conformity and substance use on victim blaming. Aggression and Violent Behavior. 2012;17:443-52 